\title{
Chapter 14 \\ Skills for a Green Economy: Practice, \\ Possibilities, and Prospects
}

\author{
John Fien and Jose Roberto Guevara
}

\section{Introduction}

The drive (though some might say 'drift') towards a greener economy comes from the growing international realisation that past and current 'brown' businessas-usual approaches to development are no longer providing the excess of economic benefits and social progress that they have in the past and so are no longer outweighing their 'negative externalities' and costs in the form of pollution, the run-down of resources and growing social and economic inequalities and vulnerabilities. As the Asian Development Bank (ADB) argues:

While industrial and agricultural production growth has lifted 521 million people from extreme poverty, progress has been accompanied by increasing pressure on the environmental carrying capacity of the region. (ADB 2011: 1)

Mitigating climate change is often presented as a trade-off between the economy and jobs on the one hand and the environment on the other. However, this is not necessarily the wisest, or most profitable way of looking at the problem. Especially, in the context of the global financial crisis of recent years, major world figures and bodies are now talking about the complementarity of economic and environmental interests. They argue that it is not only possible to have prosperity, jobs and inclusive growth in a low-carbon economy but also that a low-carbon economy is the only way that we will have prosperity, jobs and inclusive growth in the future.

\footnotetext{
J. Fien $(\square)$

Sustainability, Design \& Social Context Office, RMIT University, Hamilton, VIC, Australia e-mail: john.fien@rmit.edu.au

J.R. Guevara

School of Global, Urban and Social Studies, RMIT University, Hamilton, VIC, Australia e-mail: jose_roberto.guevara@rmit.edu.au
} 
This means that what is now been talked about as 'green growth', a 'green economy' or a 'green new deal' has four interconnected and mutually dependent goals:

- Increasing economic growth

- Reducing unemployment

- Increasing social inclusion and equity

- Reducing greenhouse gas emissions

A 2011 report prepared for the German Ministry of Education and Science argues that working towards these four goals in a synergistic way will reinforce the scope of each one more than if each was acted on separately. Thus, the report argues that increasing the EU's current emissions reduction target, from $20 \%$ to $30 \%$ by 2020 , would revitalise the European economy, independently of what the rest of the world decides in Durban in terms of climate policy. Seizing that opportunity would increase the size of Europe's economy by up to 5\% over the next decade, increase GDP by $€ 800$ billion and create 6 million new jobs by 2020 (Jaeger et al. 2011).

\section{What Is the Green Economy?}

The UNEP report, Green Economy Pathways to Sustainable Development and Poverty Eradication, defines a green economy as follows:

UNEP defines a green economy as one that results in improved human well-being and social equity, while significantly reducing environmental risks and ecological scarcities. In its simplest expression, a green economy can be thought of as one which is low carbon, resource efficient and socially inclusive. (UNEP 2011: 1; italics in original)

This interesting form of words, especially those in italics (in original), matches both the focus of the Rio+20 conference and the four goals of the EU report. And this is the interesting thing about the green economy concept. It grew very rapidly and has achieved high level and widespread acceptance and understanding within a very short period of time, unlike its predecessor 'sustainable development' which has been subject to widespread (mis-) appropriation, dilution and confusion. There are three dimensions to a green economy. These are:

1. Widespread respect for, and costing of, ecosystem services so that the air, water, soils, forests, crops, minerals and energy resources we consume reflect a policy of living off the interest on natural capital rather than widespread borrowing of our share from future generations, thereby mortgaging the future of human society. Figure 14.1 illustrates the breadth of the ecosystem services, just in terms of biodiversity (Column 1), that underpin all development (Column 2) and the economic value of a sample of these services from biodiversity (Column 3).

2. The dematerialisation of agricultural and industrial processes will drastically reduce the energy and natural resources that flow through the economy, restrict the rate of resource depletion, reduce pollution and waste, make more efficient 


\begin{tabular}{|l|l|l|}
\hline \multicolumn{1}{|c|}{ Biodiversity } & \multicolumn{1}{|c|}{$\begin{array}{c}\text { Ecosystem goods and } \\
\text { services (examples) }\end{array}$} & Economic values (examples) \\
\hline $\begin{array}{l}\text { Ecosystems } \\
\text { (variety \& extent/area) }\end{array}$ & $\begin{array}{l}\text { Recreation } \\
\text { - Water regulation } \\
\text { Carbon storage }\end{array}$ & $\begin{array}{l}\text { Avoiding GHG emissions by conserving } \\
\text { forests: US\$ } 3.7 \text { trillion (NPV) }\end{array}$ \\
\hline $\begin{array}{l}\text { Species } \\
\text { (diversity \& abundance) }\end{array}$ & $\begin{array}{l}\text { - Food, fibre, fuel } \\
\text { Design inspiration }\end{array}$ & $\begin{array}{l}\text { Contribution of insect pollinators to } \\
\text { agricultural } \\
\text { output: US } 190 \text { billion/year }{ }^{24}\end{array}$ \\
\hline $\begin{array}{l}\text { Genes } \\
\text { (variability \& population) }\end{array}$ & $\begin{array}{l}\text { Medicinal discovery } \\
\text { Disease resistance }\end{array}$ & $\begin{array}{l}25 \%-50 \% \text { of the USS } 640 \text { billion } \\
\text { pharmaceutical market is derived from } \\
\text { genetic resources }\end{array}$ \\
\hline
\end{tabular}

Fig. 14.1 Biodiversity ecosystem services underpinning a green economy Source: UNEP (2011) p. 8.

use of energy and mitigate $\mathrm{CO} 2$ emissions into the atmosphere, thereby addressing human-induced contributions to global warming.

Dominic Barton, Managing Director of McKinsey \& Company for Asia, argues that

Over the next 5 years, we expect Asian governments to focus on 'green growth'. This will be driven by energy security and resource sustainability overall, as well as by economic and environmental sustainability - including the global response to climate change. (Barton 2010)

He argues that both governments and businesses will move forward together on this through public-private partnerships that mobilise capital for low-carbon investment and innovations in resource productivity and energy efficiency, as well as by consumer demand and the setting of market prices for previously 'free' natural resources. Indeed, he argues that 'the push for green growth will create real market prices for resources previously considered free, cheap or external to the market-principally carbon, but also water, forested land, waste and biodiversity' and that this will 'have a seismic impact on global markets and ways of doing business'.

3. An insistence on social equity and inclusion through clean and decent jobs. The UNEP Green Economy Pathways report found what it described as an inextricable link between poverty eradication and better maintenance and conservation of the ecological commons, arising from the benefit flows from natural capital that are received directly by the poor' (UNEP 2011: 6). For example, the ILO reports on the National Rural Employment Guarantee Scheme (NREGS) in India. This public work programme enhances the livelihood security of rural households by providing at least 100 days of paid work each year to qualified households. The conservation of ecosystem services is a major feature of the programme and includes work in water conservation, drought-proofing (including plantation and afforestation), flood protection, small-scale irrigation, horticulture and land development - and involved over 3 billion workdays across 59 million families in 2009-2010.

However, despite this example, four key points can be made about the transition to a green economy: 
Firstly, government-funded work is not where most green jobs will be. We used the Indian example just to show the potential of green work to support poverty reduction programmes.

Secondly, many green jobs will be highly skilled and will be found in cities in areas such as construction, energy and water utilities, transport and manufacturing, as well as the countryside.

Thirdly, whether in cities or the countryside, many of these jobs are in lesswell-regulated sectors and thus have poor health and safety records and industrial conditions. A green economy must address these issues to provide what the ILO calls 'clean and decent work'.

Finally, there is a gender equity dimension to jobs in a green economy. Indeed, the International Labor Foundation for Sustainable Development (Sustainlabour) argues that the green economy should:

- Aim to satisfy human needs: providing universal access to water, food, health, housing, education, transport and culture

- Be based on justice: be capable of distributing the costs and benefits fairly, between and within countries

- Be inclusive: young people, women. . everyone must be part of it!

- Be a real economy: do away with the speculative economy and the economic, financial and real estate bubbles

- Be based on the four pillars of the Decent Work Agenda: full employment, guarantee labour and trade union rights, social protection and dialogue and participation (Sustainlabour 2011)

These important criteria remind us of the key definition of a green economy as one that 'results in improved human well-being and social equity, while signifcantly reducing environmental risks and ecological scarcities. In its simplest expression, a green economy can be thought of as one which is low carbon, resource efficient and socially inclusive' (UNEP 2011: 1; italics in original)

\section{Green Jobs, Green Skills, and TVET}

This social dimension of a green economy draws attention to the area of human capital formation. Thus, the ILO International Institute for Labor Studies (2011) argues that

This will require that the existing education system and vocational training system be capable of equipping future workers and small and medium-sized businesses with the requisite breadth of competences needed to take full advantage of the new technologies. In particular, mechanisms to facilitate the effective generation and transmission of knowledge between higher education institutions and business will be central.... If the right human capital strategies are implemented, a green economy can unlock the potential of higher employment, better employment conditions and higher resource productivity. (p. 6) 
A significant barrier, however, to developing appropriate human capital strategies is a widespread lack of clarity about what green jobs actually are, and until you know what jobs are involved, it is very difficult to identify the sort of training that needs to be planned and provided. Thus, Wilson (2009) argues that it may be more helpful to think in terms of green skills for jobs and that these might be classified in the following way:

- Existing jobs will all require additional skill sets related to ethics and sustainability. Some will be affected more than others, requiring new expertise and some new technical skills - trades and engineering, for example.

- New jobs in existing industries which derive from the climate change adaptation initiatives - new mix of technical skills plus ethics, as might be found in mining or construction industries.

- New and expanded industries using existing technical skills plus ethical understanding and new technical skills, such as might be found in renewable energy sources.

- New and expanded industries using new occupations (technical skills plus ethics and sustainability, yet to be developed) (p. 2).

Skills development for employability and sustainability has received major attention in recent years, beginning with the UNESCO Intergovernmental Conference on TVET in the Republic of Korea in 1999 (UNESCO 1999) and continued by the work of UNESCO-UNEVOC International Centre. These initiatives are well summarised in UNESCO-UNEVOC's TVETipedia (2011), its 2004 Bonn Declaration and its publication Reorienting Technical and Vocational Education for Sustainable Development (Fien and Wilson, 2004). And case studies of ways in which governments and TVET systems around the world are beginning to respond may be found in a book, its commissioned book, Work, Learning and Sustainability (Fien et al. 2008).

\section{Case Studies}

We would like to illustrate the range of pathways to promoting skills for a green economy through two case studies. The first is of the Green Skills Agreement and associated initiatives being implemented by the Australian government. The second draws from the work of the regional NGO, Asia South Pacific Association for Basic and Adult Education (ASPBAE).

\section{Australian Green Skills Agreement}

A 2009 survey by the programme of nearly 2,000 employers in Australia indicated that nearly half of all businesses surveyed (approximately 48\%) said they had been affected by environmental or sustainability issues in the last 12 months, either 
'slightly', 'quite a bit' or 'a lot'. Some industries were much more strongly affected than others, especially in construction, mining and electrical industries.

When asked what these effects were, they identified three factors:

- Rising costs of compliance, energy or other factors related to environmental issues and changing environmental standards in their industries

- Ethical considerations: ethical considerations were a significant consideration for almost half (49\%) of the businesses responding to this question

- Government legislation, regulations

When asked if they expected environmental and sustainability issues to affect their skills needs over the following 12 months, about a quarter said they thought their business would be affected. There was a high level of uncertainty in this period, with about $20 \%$ selecting 'don't know'. However, comparatively more respondents (38\%) thought there would be a skills impact in the next 3-5 years.

This is the background against which a Green Skills Agreement has been forged in Australia, involving the Australian and state and territory governments, employer and employee representatives, the VET sector and community organisations. The aim of the agreement is to build the capacity of the VET sector to deliver the skills for sustainability required in the workplace that will enable individuals, businesses and communities to adjust to, and prosper in, a sustainable, low-carbon economy. The objectives of the agreement are:

- To develop national standards in skills for sustainability within the requirements of the national regulatory framework

- To upskill VET practitioners so they can provide effective training and facilitation in skills for sustainability

- To undertake a strategic review of Training Packages (sets of nationally endorsed standards and qualifications for recognising and assessing people's skills) to embed sustainability knowledge, skills and principles

- To implement a transition strategy to reskill vulnerable workers

A number of programmes have been developed to meet these objectives. These include:

- A National VET Sector Sustainability Action Plan (NVSSAP) 2009-2012 was developed in 2009.

- The Australian Government established a Teaching and Learning Capital Fund for Vocational Education and Training (VET) valued at \$500 million to modernise and improve the quality and sustainability of VET buildings.

- A Skills for the Carbon Challenge provides national leadership in building the capacity of the tertiary education sector to supply the skills needed for workers and businesses to prosper in a low-carbon economy. This involves:

- Investing in research to develop a better understanding of the underlying skills issues associated with the transition to a low-carbon economy and appropriate responses 
- Presenting the skills for sustainability - Educational Institution Award to encourage excellence in the delivery of education and training for sustainability

- A Clean Energy and Other Skills Package is investing \$32 million over 4 years to enable tradespeople and professionals in key industries to develop the skills needed to deliver clean energy services, products and advice to Australian communities and businesses.

\section{Asia South Pacific Association for Basic and Adult Education (ASPBAE)}

An ASPBAE study of TVET in the Philippines conducted by Magpusao (2011) observed that the increasing demand from the labour market for individuals with technical and vocational skills has resulted in the TVET pathway being more aggressively promoted. This was equally a response to the demand from the business community to address the mismatch between education provision and the needs of the market. The 'Education Highway' programme of the former President Gloria Macapagal-Arroyo argued that generating employment through vocational-technical skills enhancement is one of the strategies need to improve the economy.

As a result, the youth were encouraged to consider TVET as a pathway to greater job opportunities and higher incomes. This was not limited to those from poorer backgrounds but was promoted through the introduction of vocational-technical secondary schools and career assessments to evaluate a student's ability for either professional work or vocational-technical work. However, despite the political promotion, in practice, secondary schools continued to provide poor-quality TVET.

While the government's Technical Education and Skills Development Authority (TESDA) offered quality training TVET programmes, the limited number of TESDA centres and service providers at the community level has made these programmes inaccessible. The prerequisite that TESDA students must be high school graduates made such programmes even more inaccessible to many Filipinos given that $51 \%$ of Filipinos are, at most, elementary graduates and almost $30 \%$ of school-age secondary students drop out of school.

The study observed that nonformal and community-based TVET training programmes conducted by NGOs for marginalised individuals tended to be more innovative and effective as a poverty alleviation strategy. Those unable to attend the formally accredited TVET programmes, like out-of-school youths and poor women and men, are able to participate because the high school diploma requirement is usually waived. Furthermore, NGO training programmes tend to integrate other elements, such as microfinance support programmes that may be linked with institutions both locally and overseas. However, the disadvantage is that these more accessible and integrated programmes are often dependent on funds from overseas aid agencies, which impacts on their long-term sustainability. 
E-Net Philippines, a civil society network that advocates for education reform in the Philippines, 'believes that TVET should be approached within the framework of Education for All Goals, specifically under Goal 3 where the commitment is to provide appropriate learning interventions for youth and adult especially for the poor and marginalised'.

Finally, the study concluded that if TVET is to truly contribute to poverty alleviation in the Philippines, it cannot be seen as a short-term solution to unemployment but should be grounded in the country's sustainable development framework. TVET must adapt to the rapidly changing demands of the labour market without focusing solely on the global need for service sector labourers. Finally, it must be viewed from a lifelong learning perspective, not just to develop skills to improving income but skills to improve lives.

\section{Summary and Conclusion}

Transitioning to a 'green economy' is more than a short-term response to current global crises. It can be a long-term strategy for sustainable development and poverty alleviation.

A 'green economy' has four interconnected and mutually dependent goals: increasing economic growth, alleviating poverty by reducing unemployment, increasing social inclusion and equity, and reducing greenhouse gas emissions.

Achieving these goals will require existing education and vocational training systems to be capable of equipping all individuals with the requisite breadth of competencies needed to take full advantage of the opportunities being generated by the 'green economy'.

Open Access This chapter is distributed under the terms of the Creative Commons Attribution Non-commercial License which permits any non-commercial use, distribution, and reproduction in any medium, provided the original author(s) and source are credited.

\section{References}

Asian Development Bank (ADB). (2011). Environment program: Greening growth in Asia and the Pacific. Manila: ADB.

Barton, D. (2010). Green growth in Asia: An opportunity for business. Global Asia, 4(4). Retrieved November 11, 2011, from http://www.globalasia.org/V4N4_Winter_2010/Dominic_Barton.html

Bird, J., \& Lawton, K. (2009). The future's green: Jobs and the UK low-carbon transition, Institute of Public Policy Research. Retrieved July 4, 2010, from www.ippr.org

Fien, J., \& Wilson, D. (2004). Reorienting technical and vocational education for sustainable development. Bonn: UNESCO-UNEVOC International Centre.

Fien, J., Maclean, R., \& Park, M. (Eds.). (2008). Work, learning and sustainability. Dordrecht: Springer.

ILO. (2011). Promoting decent work in a green economy. Geneva: ILO. 
ILO, \& International Institute for Labor Studies. (2011). Towards a greener economy: The social dimension. Geneva: ILO/IILS.

Jaeger, C., \& Kupers, R. (2011). A green return to European growth. [The People's Republic of] China Daily, 21 February 2011. Retrieved October 2, 2011, from http://www.chinadaily.com. cn/thinktank/201102/21/content_12052404.htm

Jaeger, C., et al. (2011). A new growth path for Europe: Generating prosperity and jobs in the lowcarbon economy. Potsdam: European Climate Forum.

Magpusao, Chris-Jerome J. (2011). Country case study: The TVET system in the Philippines. In Breaking ground: Towards an advocacy framework for TVET and life skills for the youth in developing countries in Asia and the Pacific. ASPBAE (Unpublished paper).

Sustainlabour. (2009). Green jobs and women workers employment, equity, equality. Madrid: International Labor Foundation for Sustainable Development (Sustainlabour).

Sustainlabour. (2011). Green economy. Retrieved November 22, 2011, from http://www. sustainlabour.org/temas.php?lang $=$ EN\&idtema $=1$

UNEP. (2011). Green economy pathways to sustainable development and poverty eradication: A synthesis for policy makers. Nairobi: UNEP.

UNESCO. (1999). Final report, second international conference on technical and vocational education. Paris: UNESCO.

UNESCO-UNEVOC. (2004). The Bonn Declaration on learning for work, citizenship and sustainability. Retrieved November 18, 2011, from http://portal.unesco.org/education/en/ev. phpURL_ID $=38169 \&$ URL_DO $=$ DO_TOPIC\&URL_SECTION $=201 . \mathrm{html}$

UNESCO-UNEVOC. (2011). TVETipedia. Retrieved November 30, 2011, from http://www. unevoc.unesco.org/tvetipedia.html?tx_drwiki_pi1[keyword]=TVEtipedia

Wilson, B. (2009). Melbourne pure case studies - theme: 'Green' jobs, PASCAL international observatory. Retrieved November 22, 2011, from http://www.pascalobservatory.org 